\title{
A importância da categoria "gênero" nos novos estudos migratórios
}

\author{
Ana Carolina Gonçalves Leite*
}

Foi com um conjunto farto de narrativas que revelam a diversidade de trajetórias e dos significados atribuídos a elas que, sobretudo pesquisadoras, atenderam ao nosso chamado para a composição de um dossiê com o intuito de apresentar alguns dos "Rostos femininos na migração". Migrantes internas permanentemente temporárias na agroindústria citrícola paulista, migrantes brasileiras na Flórida ou em Lisboa, além de peruanas, chilenas, paraguaias, colombianas, bolivianas e japonesas no Brasil ou noutros países da América Latina tiveram seus caminhos, histórias, memórias, reflexões, críticas, vontades, sonhos delicadamente retratados em trabalhos que avançaram também perguntas importantes sobre o caráter atual das migrações e sua relação com a inserção polissêmica das mulheres nesse processo.

Nos debates que integram aquela que se tornou a chamada "questão migratória", ao menos desde o clássico "As leis da migração", de Ernst Georg Ravenstein, publicado na penúltima década do século XIX, no Reino Unido, a centralidade assumida pelo trabalho entre as motivações que impulsionam os migrantes vem sendo sempre referida. Seria, todavia, apenas a partir da segunda metade do século XX, diante das profundas transformações em escala mundial transcorridas na reprodução capitalista assim como nas práticas sociais, suas representações, instituições e na forma de interpretá-las, inclusive no campo acadêmico-científico, que dessa referência seria desdobrado distinto, ainda que derivado, problema de investigação.

Considerado o trabalho entre as principais motivações dos migrantes, esse migrante devia ser pensado também como trabalhador - e como trabalhador teria um corpo a se deslocar e produzir simultaneamente o espaço para os seus deslocamentos. Ficava ensaiada uma poderosa crítica a uma concepção cartesiana das migrações e o espaço do deslocamento não podia mais ser entendido como um plano em que pontos desenhariam retas ou curvas.

Um importante leitor da obra de Michel Foucault, hoje pouco lembrado nos estudos sobre as migrações, investigaria a questão acima apresentada analisando

*Doutora em Geografia pela USP. 
a produção de corpos docilizados (cf., por exemplo, Gaudemar, 1981). Outro, brasileiro, seguiria pela mesma senda, mas dedicado especialmente à própria questão migratória como um campo modulado pela possibilidade e necessidade, do ponto de vista da reprodução das relações historicamente estabelecidas, de controle dos corpos dos trabalhadores (cf., por exemplo, Vainer, 1984).

Da apreensão do migrante como trabalhador - e do fundamento das modernas migrações no estabelecimento histórico de uma sociedade do trabalho - e do trabalhador com um corpo, seriam dados passos possíveis em direção ao reconhecimento das diferenças, especialmente aquelas marcadas socialmente pelo registro da desigualdade, hierarquia e formas de dominação, mediante as quais os mesmos se inseririam nas tramas de relações e representações sociais. Uma intersecção entre questão de gênero e questão migratória nasceria desde aí - e não só ela, assim como intersecções com as dimensões da etnia, religiosidade e identidade dos processos sociais.

Outro caminho interpretativo também teria como base a questão das motivações dos migrantes para daí derivar uma corporalidade necessária à consideração da questão migratória. Ao invés de perseguir o traçado aqui redesenhado com poucas linhas graúdas das motivações ao migrante, dele ao trabalhador, esse com um corpo, o mesmo abordaria a ideia de motivação encontrando nela, mais ou menos pressuposto, um sujeito que deseja, projeta, escolhe.

Como lembrado na apresentação da última edição da revista Travessia, pensadas como fato social total (cf., por exemplo, Sayad, 1998 e, antes dele, Mauss, 2005 [1950]), as migrações ganhariam contornos numa espécie de quadro multivetorial que incluiria, entre outros, aspectos culturais, políticos, de gênero, identitários, relativos à saúde, e, porque não, relativos também ao trabalho. Diferentemente da construção sugerida antes, na qual a existência enquanto trabalhador definia o campo da formação do sujeito que nele deseja e cujas motivações incluiriam, inclusive, a busca por trabalho, aqui sujeitos e condicionamentos eram tomados em sua existência independente, a partir da qual estabeleceriam interações que (trans)formariam os primeiros e, com eles, concomitantemente os últimos, mas sempre considerados, ambos, a priori. Por conseguinte, política, economia, cultura, família, identidades corresponderiam a campos dotados de autonomia relativa cuja conjugação teria em vista certa perspectiva de totalidade apreensível nos corpos dos sujeitos, sínteses de condicionamentos.

Embora não tenha sido tematizada explicitamente, essa linha tênue que divorcia pontos de vista, cujas diferenças hoje em dia se encontram bastante esfumadas, apareceria, entretanto, na diversidade de perguntas que foram desdobradas da apresentação dos rostos das mulheres migrantes feitas pelas pesquisas aqui reunidas. 
Com o objetivo de apresentar a expressividade feminina nos processos migratórios para a agroindústria paulista, as autoras Lidiane Maciel e Giovana Gonçalves Pereira ofereceram, em seu artigo, "A face feminina na migração permanentemente temporária no Estado de São Paulo: o caso das trabalhadoras da citricultura", relatos e observações preciosas sobre as condições de trabalho experimentadas por mulheres nos laranjais, observando o problema do trabalho feminino aparecer como complementação ao masculino, mas também o da individualização decorrente do auferimento de renda pelas mulheres, a produzir inúmeros desdobramentos na forma que assume a dominação masculina assim transformada. Dessa caracterização, as autoras desdobrariam, contudo, questionamentos sobre o próprio processo que constituiria determinada migração feminina num contexto de emergência de novas funções decorrentes da reestruturação produtiva da agroindustria brasileira, como as de "catadoras de pedras" ou "bituqueiras", que surgiram com o processo bastante recente de mecanização do corte da cana-de-açúcar, na medida em que aqueles novos degradados postos de trabalho fariam com que as mulheres se tornassem, nas palavras das autoras, uma "mão-de-obra atrativa".

Diferentemente, perguntando-se sobre mudanças mais profundas nos processos sociais a intaragirem com novas características das migrações, Valéria Barbosa Magalhães, em conjunto com José Renato de Campos Araújo, e Juliana dos Santos Pereira Moraes, dariam destaque, nos seus respectivos artigos "Rostos femininos nas migrações internacionais: mulheres brasileiras no Sul da Flórida" e "Rostos goianos na migração", para a inversão da tradicional posição do Brasil enquanto país em tese receptor de migrantes e para os efeitos da chamada última crise mundial, cujo epicentro ocorrera em 2008, observando processos sem apresentá-los do ponto de vista da sua especificação de gênero. Migrações contemporâneas de brasileiras para a Flórida, nos Estados Unidos, contraporiam uma caracterização essencialista das posições de cada país nas migrações internacionais e sofreriam modificações com a crise, responsável por restringir a viabilidade de uma inserção economica no destino, desencadeando inclusive a adoção de novas rotas, como alternativa para a realização dos projetos migratórios.

A questão de gênero apareceria contornada mais pelos relatos de experiência daquelas mulheres migrantes que permitiam entrever, para a reelaboração dos papéis sociais, a importancia da experiência em processos de socialização que tencionam com o que é tradionalmente esperado no Brasil, em termos de dominação masculina, mas também a repetição de determinados conteúdos sociais nas trajetórias das mulheres que migram para acompanhar os projetos de seus maridos ou daquelas que, migrando sozinhas, sofrem com estereótipos de gênero que associam certo ideial de cultura brasileira a caracterizações que se pretendem humilhantes da sexualidade/sensualidade das migrantes. 
É na caracterização da experiência particular das mulheres num processo migratório não especificado desse ponto de vista que a questão de gênero se apresenta também no trabalho "Mulheres japonesas e suas famílias: migração e colonização privada no estado de Mato Grosso - 1952", da autora Aldina Cássia Fernandes da Silva. É retomado o problema clássico da colonização, nesse caso, privada, das fronteiras do território nacional em formação com imigrantes estrangeiros.

Os papéis de gênero e as relações de dominação seriam analisados na relação com as particularidades culturais daqueles grupos japoneses migrantes, embora a valoração de certas atividades como femininas também coincidisse com velhas conhecidas da "nossa" cultura ocidental. Para além das oposições entre cozinhar e derrubar árvores com a machado, aparecia todavia na trama do gambarê, que pode ser traduzido como a luta dos japoneses para ter sucesso, a emergência de uma família de decisões fortemente centralizadas pelo patriarca, diante da qual as mulheres tinham que operar estratégias de modo a tentarem fazer valer suas escolhas, como a de não ter tantos filhos ou não aceitar pretendentes que não escolheram de maneira autonoma.

Essa caracterização é igualmente o fundamento no artigo de Tatiana Chang Waldman e Maria Angélica Beghini Morales, "Mulheres em movimento: registrando memórias migrantes", dedicado a apresentar um dos projetos de caracterização das migrações contemporâneas na coleção de História Oral do Museu da Imigração. Mas as experiências de migração, nesse trabalho, aparecem contornadas por processos coletivos de organização de mulheres migrantes que pontuam, para além do atual estado de coisas, as perspectivas dessas mulheres de ampliação do respeito às diferenças culturais mediante a implantação de políticas públicas específicas, por exemplo, ligadas à saúde e às condições de parto, mas também à facilitação na regularização e no acesso ao aprendizado do idioma e seu processo comum de fortalecimento diante de dificuldades que decorrem do fato de ser mulher e migrante.

Caracterizações como essas ganhariam um aparato conceitual para sua interpretação no artigo "Relatos de discriminação negativa em países sudamericanos", de Elizabeth Ruano e Patrícia Nabuco Martuscelli. As autoras partem da perspectiva de que o próprio privilegiamento das mulheres enquanto sujeitos faria a dimensão de gênero das vivências migratórias ganhar centralidade. Tais vivências, com respeito à sua especificação de gênero, seriam pensadas mediante o conceito de discriminação negativa pontuado para discutir tanto os prejuízos para certas particularidades identitárias do "outro" como os limites das atuais disposições dos tratados internacionais que regulam a inserção dos migrantes. Uma caracterização particularizada dos hodiernos processos migratórios seria organizada, todavia, partindo da análise dos fatores 
que incentivam a migração da Colombia para o Equador e do Paraguai para o Brasil, mas daquelas populações como um todo.

Assim, também nas narrativas apresentadas no relato "Vozes de mulheres migrantes não apenas em 8 de março", da mesma Elizabeth Ruano, onde nacionalidade, idade, profissão, status migratório e questão de gênero são investigados do ponto de vista do impacto que produzem sobre a possibilidade do migrante ter voz diante de condições, as quais, de uma maneira ou de outra, são contornadas pela discriminação negativa. Na condição de relato, contudo, a construção viria definida sobretudo pelas experiências de sofrimento que a discriminação produz, diferenciada mesmo das interpretações que partem de memórias e narrativas, como revela de maneira significativa um fragmento do depoimento de Erika onde ela diz: "As dores que eu tenho não podem ser quantificadas".

Um caminho mais próximo àquele ensejado pelo primeiro texto que apresentamos apareceria, finalmente, no artigo de Clara Lemme Ribeiro, "A feminização como tendência da migração boliviana para São Paulo". Como na totalidade dos trabalhos que compõe esse dossiê, a autora traria também as experiências de discriminação, humilhação e sofrimento, mas avançaria ainda uma pergunta sobre o processo contemporâneo identificado como feminização das migrações, refletindo se novas eventuais características dessas últimas se relacionariam com processos de empoderamento feminino ou de feminização da pobreza.

Em seu conjunto, os trabalhos que agora apresentamos revelam o quão profícua se tornou a categoria "gênero" na produção de reflexões sobre as experiências dos sujeitos sociais em suas particularidades, incluídas aqui as exeperiências de mulheres migrantes, a ponto de exigir esforços de ruptura epistemológica das ciências sociais de modo a incluir em suas análises um sujeito apresentado em suas particularidades, entre outras, também identitárias, étnicas, religiosas ou nacionais. Possibilitam ainda, todavia - e essa consideração não é trivial para a perspectiva de incorporação do "gênero" enquanto categoria de análise necessária às investigações sociais - um reconhecimento da potência que teria a incorporação da mesma para pensar a própria migração, suas formas sociais em processo e seu caráter mais atual. 


\section{Referências}

GAUDEMAR, Jean-Paul. La movilizacion general. Seseña/Madrid: Las ediciones de la piqueta, 1981.

MAUSS, Marcel. Sociologia e antropologia. São Paulo: Cosacnaify, 2005.

RAVENSTEIN, Ernest George. [1885] As leis das migrações. Trad. Hélio A. Moura. In: MOURA, Hélio A. (org.) Migração interna, textos selecionados. Fortaleza, BNB/ENTENE, 1980, p.2588, 722p.

SAYAD, Abdelmaleck. A imigração ou os paradoxos da alteridade. São Paulo. Edusp, 1998.

VAINER, Carlos. Trabalho, espaço e Estado: questionando a questão migratória. Rio de Janeiro: mimeo., IPPUR, UFRJ, 1984. 